\title{
PEMBENTUKAN ASAM HUMAT DAN FULVAT SELAMA PEMBUATAN KOMPOS JERAMI PADI
}

\author{
Agustian, Petria Susila dan Gusnidar \\ J urusan Tanah F akultas Pertanian U niversitas Andalas Padang
}

\begin{abstract}
Production of humic substances during the composting of organic matter becomes one criterion of compost quality. The objectives of this study were to measure and quantify the amounts of humic substances produced during the composting of rice straw by commercial decomposer, Effective Microorganism 4 (EM4). The experiment was carried out by using twenty kilograms of rice straw with $\mathrm{C} / \mathrm{N}$ ratio 105 and containing $32.28 \%$ of cellulose and $4.48 \%$ lignin. The treatment essayed was the quantity EM4 applied i.e 10, 20, $30 \mathrm{ml}$ and without inoculation as control. Experimental design used was Completely Randomized Design with three replications. Parameters observed are $\mathrm{C} / \mathrm{N}$ ratio, humic acid, fulvic acid, and humification ratio. The results clearly showed that the increase of EM4 applied was closely related with the sum of humic substances, humic acid, and fulvic acid produced. The significance results were observed after 60 days applying compost with $30 \mathrm{ml}$ EM4. It could be concluded that the quantity of EM4 applied to determine the rate of compost maturity as indicated by the value of humification ratio, was significantly different. On the other hand, the low contents of lignin in rice straw might also determine humic and fulvic acid formation.
\end{abstract}

Key words : Rice straw, compost, humic acid, fulvic acid

\section{PENDAHULUAN}

Jerami padi merupakan batang dan daun padi sebagai produk sisa dari hasil panen. Tangenjaya (1991) menyatakan bahwa dalam satu hektar sawah sisa panen berupa jerami padi dapat ditemukan sebanyak 40 ton. Sejauh ini menurut Darwis, Bunasor, Hartarto dan Sailah (1988) pemanfaatan jerami padi yang pernah dilakukan adalah : makanan ternak, bahan bakar, media penanaman jamur dan industri kertas serta sebagai bahan kompos. Dalam sistem pertanian tradisional biasanya jerami padi tersebut dikembalikan ke dalam tanah atau dibakar dan abunya digunakan sebagai pupuk. Pemberian jerami tersebut tanpa melalui proses pengomposan terlebih dahulu mengandung resiko besar karena nisbah $\mathrm{C} / \mathrm{N}$ nya terbilang tinggi.

Kematangan kompos yang didefinisikan sebagai tingkat kestabilan fisik, kimia dan biologis kompos merupakan faktor penting dalam penggunaannya dalam bidang pertanian dan dampaknya terhadap ling

kungan. .Penggunaan kompos yang belum matang dengan nisbah $\mathrm{C} / \mathrm{N}$ yang masih tinggi ke dalam tanah akan menyebabkan terjadinya imobilisasi $\mathrm{N}$ yang akan menimbulkan defisiensi $\mathrm{N}$ dalam tanah. Sebaliknya kompos yang belum matang dengan nisbah $\mathrm{C} / \mathrm{N}$ yang sangat rendah cenderung mengakibatkan keracunan $\mathrm{NH}_{3}$ terhadap tanaman (Inbar, Chen dan Hadar, 1990).

Pengomposan merupakan suatu proses dekomposisi atau perombakan bahan organik padat ke dalam bentuk bahan humik yang relatif tahan terhadap pelapukan. Proses dekomposisi ini dilakukan oleh berbagai mikroorganisme termasuk bakteri, aktinomisetes dan jamur yang umumnya bersifat aerobik. Menurut $\mathrm{He}$, Traina dan Logan (1992), berbagai faktor dapat mempengaruhi sifat dan ciri kompos yang dihasilkan antara lain: pertama sumber atau 
asal bahan organik yang dikomposkan, kedua praperlakuan yang diberikan, ketiga temperatur selama pengomposan, keempat kelembaban, kelima aerasi dan keenam lamanya pengomposan berlangsung. Faktor yang pertama akan menentukan kemudahan terhadap perombakan, faktor kedua akan menentukan kandungan kompos, sedangkan faktor ke tiga sampai lima akan menentukan kecepatan perombakan dan yang terakhir faktor keenam umumnya akan menentukan tingkat kematangan. Menurut Gaur (1982) selain faktor-faktor diatas peranan mikroorganisme perombak juga sangat penting. Penambahan inokulan perombak akan dapat mempercepat proses pengomposan dan meningkatkan kualitas kompos yang dihasilkan.

Terdapat banyak sekali metoda yang telah dikembangkan dalam menilai tingkat kematangan dan kualitas kompos. Inbar et al. (1990) menilai tingkat kematangan melalui nilai nisbah humifikasi selama pengomposan. Secara garis besar $\mathrm{He}$ et al. (1992) mengelompokkan metoda-metoda tersebut atas : analisis sifat kimia, analisis sifat fisik, analisis biologis, uji tanaman, spektroskopik dan tingkat humifikasi. Dikarenakan sangat beragamnya bahan asal dari kompos maka sangat tidak mungkin hanya menggunakan satu metoda saja dalam evaluasi tingkat kematangan kompos. Biasanya digunakan kombinasi dari beberapa metoda seperti sifat kimia dan biologis

Tujuan penelitian ini adalah untuk menghitung kandungan asam humat dan asam fulvat dalam menilai kematangan kompos serta mempelajari peranan effective microorganism (EM4) dalam proses pengomposan jerami padi..

\section{BAHAN DAN METODE}

Penelitian ini dilakukan dengan menggunakan jerami padi kering panen sebanyak $20 \mathrm{~kg}$. Dalam proses pembuatan Bokhasi (kompos fermentasi) digunakan mikroba perombak yang diperdagangkan dengan merek Effective Microorganism 4 (EM4) yang diproduksi oleh Indonesian Kyusei Nature Farming Societies Jakarta. Bahan jerami yang digunakan mengandung selulosa 32,28\%, lignin $4,48 \%$ dengan nisbah $\mathrm{C} / \mathrm{N}$ 105. Bahan tambahan lainnya adalah dedak $0,5 \mathrm{~kg}$, gula pasir $100 \mathrm{~g}$, dan larutan EM4 sesuai dengan perlakuan. Dosis yang digunakan dalam penelitian ini 0,10 , 20 dan $30 \mathrm{ml} \mathrm{EM} 4$ per $20 \mathrm{~kg}$ jerami padi. Percobaan ini menggunakan Rancangan Acak Lengkap (RAL) dengan 3 kali ulangan. Uji lanjutan menggunakan Duncan's New Multiple Range Test (DNMRT) pada taraf nyata $5 \%$.

Pengamatan yang dilakukan selama pengomposan adalah kandungan bahan humik, jumlah asam humat dan fulvat, nisbah $\mathrm{C} / \mathrm{N}$, nisbah humifikasi pada umur kompos 20, 40 dan 60 hari serta rendemen kompos yang dihasilkan. Ekstraksi bahan humik dilakukan dengan menggunakan larutan $\mathrm{NaOH} 0,1 \mathrm{~N}$, selanjutnya pemisahan asam humat dan fulvat dilakukan pengasaman dan sentrifugasi mengikuti prosedur Tan, 1996. Sebanyak $1 \mathrm{~g}$ contoh kompos yang telah dihaluskan dikocok dengan $25 \mathrm{ml} \mathrm{NaOH} 0,1 \mathrm{~N}$ selama 24 jam, kemudian disentrifus pada kecepatan 10.000 rpm pada suhu $4{ }^{\circ} \mathrm{C}$ selama 15 menit untuk memisahkan larutan dengan bahan kompos atau residu. Residu kemudian dicuci dengan $25 \mathrm{ml}$ aquades dan disentrifus kembali selama 15 menit pada kecepatan $15.000 \mathrm{rpm}$. Filtrat yang diperoleh dari hasil sentrifugasi kemudian disaring dengan kertas saring Whatman 40 dan diasamkan dengan menambahkan $25 \mathrm{ml}$ 
$\mathrm{HCl} 0,1 \mathrm{~N}$ sehingga asam humat mengendap dan dibiarkan selama 24 jam. Selanjutnya asam humat yang mengendap dipisahkan dari asam fulvat yang ada dalam larutan dengan sentrifugasi dengan kecepatan $15.000 \mathrm{rpm}$ selama 10 menit. Asam humat yang terkumpul di dasar tabung kemudian dikeringkan dalam oven pada suhu $60{ }^{\circ} \mathrm{C}$ begitu juga dengan filtrat yang mengandung asam fulvat. Berat yang diperoleh merupakan berat asam humat dan fulvat yang dikandung kompos.

\section{HASIL DAN PEMBAHASAN}

\section{a. Asam humat dan fulvat}

Kandungan asam humat maupun asam fulvat telah terbentuk setelah 20 hari pengomposan dengan jumlah asam fulvat jauh lebih tinggi dibandingkan dengan asam humat. Pada umur kompos 20 hari jumlah asam humat yang terbentuk belum berbeda nyata antar perlakuan yang dicobakan, sebaliknya peningkatan dosis pemakaian EM4 sudah memperlihatkan pengaruh dimana pada taraf $30 \mathrm{ml}$ ditemukan sebanyak $182,67 \mathrm{mg} \mathrm{g}^{-1}$ asam fulvat yang berbeda nyata dengan taraf pemakaian yang lebih rendah.

Seiring dengan lamanya pengomposan kandungan asam humat secara perlahan meningkat, sementara asam fulvat terlihat sudah menurun jumlahnya pada umur kompos pada umur 60 hari.Hasil yang diperoleh dalam percobaan ini sejalan dengan apa yang dikemukakan oleh Inbar et al. (1990) dimana dikatakan bahan organik yang perombakannya baru pada tahap awal biasanya mengandung asam fulvat lebih banyak dibandingkan asam humat dan jika perombakannya telah berlanjut asam fulvat menurun atau tetap jumlahnya sedangkan asam humat justru meningkat.

\section{b. Nisbah $\mathrm{C} / \mathrm{N}$}

Dari hasil yang ditampilkan pada Tabel 2 terlihat bahwa nisbah $\mathrm{C} / \mathrm{N}$ setelah 20 hari pengomposan menurun dari 105 pada awal pengomposan menjadi 94,8 pada perlakuan tanpa EM4 yang berbeda nyata dengan perlakuan pemberian EM4. Nisbah $\mathrm{C} / \mathrm{N}$ terlihat menurun lebih rendah dengan peningkatan jumlah pemakaian EM4, namun demikian tidak terdapat perbedaan yang nyata antara pemberian 10, 20 dengan $30 \mathrm{ml}$ EM4.

Dari Tabel 2. Juga dapat kita lihat bahwa nilai $\mathrm{C} / \mathrm{N}$ menurun seiring dengan lamanya waktu pengomposan sedangkan pemberian EM4 dalam hal ini tidak memberikan pengaruh yang nyata terhadap perubahan nilai $\mathrm{C} / \mathrm{N}$ sampai kompos berumur 60 hari.

Menurut Dalzel et al. (1987) proses pengomposan sangat tergantung kepada aktivitas mikroorganisme perombak. Mikroorganisme membutuhkan sumber C untuk mendapatkan energi dan $\mathrm{N}$ sebagai bahan untuk pembentukan dan perbanyakan sel. Tanpa adanya sumber $\mathrm{C}$ dalam bentuk gula sederhana dan $\mathrm{N}$ yang cukup maka proses perombakan akan berlangsung lambat. Semakin tinggi nisbah $\mathrm{C} / \mathrm{N}$ bahan organik yang akan dirombak akan semakin lama terbentuk bahan humus. Singer dan Munns (1987) menyatakan bahwa proses dekomposisi bahan organik menjadi humus dalam lingkungan alami tanpa tambahan inokulan dari luar membutuhkan waktu yang panjang yaitu lebih kurang 300 hari. Oleh sebab itulah untuk memacu aktivitas mikroorganisme dalam proses dekomposisi bahan organik dengan Nisbah $\mathrm{C} / \mathrm{N}$ tinggi sering ditambahkan nutrisi seperti $\mathrm{N}, \mathrm{P}, \mathrm{K}$, $\mathrm{Mg}$ dan S.

\section{c. Tingkat Humifikasi}

Tingkat humifikasi atau tingkat dekomposisi bahan organik selain dapat di ekspresikan dengan nilai $\mathrm{C} / \mathrm{N}$ juga dapat dinyatakan dalam bentuk nisbah humifikasi yang merupakan perbandingan antara fraksi asam humat dengan asam 
Tabel 1. Kandungan asam humat (AH) dan asam fulvat (AF) selama 60 hari pengomposan jerami padi

\begin{tabular}{|c|c|c|c|c|c|c|}
\hline \multirow{2}{*}{$\begin{array}{c}\text { Perlakuan } \\
\text { (EM4) }\end{array}$} & \multicolumn{2}{|c|}{20 hari } & \multicolumn{2}{|c|}{40 hari } & \multicolumn{2}{|c|}{60 hari } \\
\hline & $\mathrm{AH}$ & $\mathrm{AF}$ & $\mathrm{AH}$ & $\mathrm{AF}$ & $\mathrm{AH}$ & $\mathrm{AF}$ \\
\hline $0 \mathrm{ml}$ & 23,94 & $161,67 \mathrm{~b}$ & 25,58 & $186,67 \mathrm{~b}$ & $26,72 a^{*}$ & 176,33 \\
\hline $10 \mathrm{ml}$ & 16,62 & $152,33 b$ & 20,87 & $211,60 \mathrm{a}^{*}$ & $25,94 \mathrm{a}$ & 185,63 \\
\hline $20 \mathrm{ml}$ & 20,79 & $168,33 \mathrm{ab}$ & 26,62 & $206,7 \mathrm{ab}$ & $46,45 \mathrm{~b}$ & 184,21 \\
\hline $30 \mathrm{ml}$ & 20,82 & $182,67 a^{*}$ & 25,59 & $188,3 \mathrm{~b}$ & $60,37 \mathrm{~b}$ & 177,58 \\
\hline
\end{tabular}

* Angka-angka pada lajur yang diikuti oleh huruf kecil yang sama berbeda tidak nyata menurut DNMRT pada taraf nyata $5 \%$.

Tabel 2. Nisbah C/N selama 60 hari pengomposan jerami padi

\begin{tabular}{|c|c|c|c|}
\hline Perlakuan & 20 hari & 40 hari & 60 hari \\
\hline \multicolumn{4}{|l|}{ EM4 } \\
\hline $0 \mathrm{ml}$ & $94,8 \mathrm{a}^{*}$ & 47,9 & 39,5 \\
\hline $10 \mathrm{ml}$ & $77,6 \mathrm{~b}$ & 44,5 & 42,9 \\
\hline $20 \mathrm{ml}$ & $75,7 \mathrm{~b}$ & 43,0 & 42,2 \\
\hline $30 \mathrm{ml}$ & $71,0 \mathrm{~b}$ & 48,2 & 37,5 \\
\hline
\end{tabular}

\footnotetext{
* Angka-angka pada lajur yang diikuti oleh huruf kecil yang sama berbeda tidak nyata menurut DNMRT pada taraf nyata $5 \%$.
} 
Tabel 3. Nisbah humifikasi (AH/AF) selama 60 hari pengomposan jerami padi

\begin{tabular}{|c|c|c|c|}
\hline Perlakuan & 20 hari & 40 hari & 60 hari \\
\hline \multicolumn{4}{|l|}{ EM4 } \\
\hline $0 \mathrm{ml}$ & 0,15 & 0,14 & $0,15 \mathrm{~b}$ \\
\hline $10 \mathrm{ml}$ & 0,11 & 0,10 & $0,14 \mathrm{~b}$ \\
\hline $20 \mathrm{ml}$ & 0,12 & 0,13 & $0,25 a b$ \\
\hline $30 \mathrm{ml}$ & 0,11 & 0,14 & $0,34 a^{*}$ \\
\hline
\end{tabular}

* Angka-angka pada lajur yang diikuti oleh huruf kecil yang sama berbeda tidak nyata menurut DNMRT pada taraf nyata 5\%.

fulvat (AH/AF). Dari Tabel 3 dapat dilihat bahwa nisbah humifikasi menaik sejalan dengan lamanya waktu pengomposan dengan EM4. Namun demikian nilai nisbah humifikasi baru memperlihatkan perbedaan yang nyata setelah kompos berumur 60 hari.

Pada umur kompos tersebut pemakaian EM4 sebanyak $30 \mathrm{ml}$ menunjukkan nisbah humifikasi yang berbeda nyata dengan perlakuan tanpa dan pemberian $10 \mathrm{ml}$ EM4 namun demikian masih tidak berbeda nyata dengan pemakaian $20 \mathrm{ml}$.

Nilai nisbah humifikasi yang diperoleh dalam penelitian ini jika dibandingkan dengan hasil penelitian Inbar et al. (1990) yang menggunakan kotoran sapi sebagai bahan kompos terbilang masih sangat rendah. Pada umur kompos 20 hari pada percobaannya nisbah humifikasi sudah mencapai lebih dari 3,0 dan pada hari ke-147 nilai nisbah telah mendekati 5,0. Rendahnya Nisbah Humifikasi yang diperoleh pada percobaan ini disebabkan karena kandungan asam fulvat yang diperoleh

fulvat yang terbentuk pada percobaan ini pada penelitian ini sampai umur 60 hari masih jauh lebih tinggi dibandingkan asam humat yang dihasilkan sedangkan hal sebaliknya dijumpai pada penelitian Inbar et al. (1990). Hal lain yang bisa menyebabkan terdapatnya perbedaan adalah karena sumber dan asal bahan yang dikomposkan juga berbeda seperti yang juga ditemui oleh Hadas dan Portnoy (1994).

\section{KESIMPULAN}

Dari hasil-hasil pengamatan yang diperoleh dapat ditarik kesimpulan sebagai berikut :

1. Dalam proses pengomposan jerami padi dengan maupun tanpa pemberian menggunakan Effective Microorganism 4 (EM4) tetap terbentuk asam humat dan asam fulvat

2. Pemakaian EM4 sebagai inokulan dalam pengomposan jerami padi dapat mempengaruhi jumlah asam humat dan

He X.T., S.J. Traina and T.J. Logan. 1992. Chemical Properties of Municipal 
pemakaian sebanyak $30 \quad \mathrm{ml}$ memperlihatkan hasil yang lebih tinggi pada umur kompos 60 hari.

3..Selain nisbah $\mathrm{C} / \mathrm{N}$ maka nisbah humifikasi (AH/AF)juga dapat digunakan dalam penilaian tingkat kematangan kompos.

\section{DAFTAR PUSTAKA}

Dalzel H.W., A.J. Biddlestone, K.R. Gray and K. Thurairajan. 1987. Soil management, compost production and use in tropical and subtropical environments. Soil Bulletin FAO. United Nations. pp 56

Darwis A.A., T.K. Bunasor, L. hartato dan I. Sailah. 1988. Laporan Tahap II studi potensi bahan lignoselulosik. PAU Bioteknologi IPB Bogor.

Hadas A and R. Portnoy. 1994. Nitrogen and Carbon Mineralization Rates of Composted Manures Incubated in Soil. J. Environ. Qual. 23: p. 1184-1189
Solid waste Composts. J. Environ. Qual. 21: p. 318-329

Inbar Y., Y. Chen and Y. Hadar. 1990. Humic Substances Formed during the Composting of Organic Matter. Soil Sci. Soc. Am. J. 54: p.1316-1323

Singer M.J. and N.M Munns. 1987. Soil and Introduction. $2^{\text {nd }}$ Edition. Mc. Millan Publishing Co.New York.

Stevenson F.J. 1982. Humus Chemistry. Genesis, composition, reactions. John Wiley and Sons, New York: pp 440

Tan, K.H. 1996. Soil Sampling, preparation and analysis. The University of Georgia. Marcel Dekker Inc. New York. Pp 408

Tangenjaya, B. 1991. Pemanfaatan limbah padi untuk pakan. Padi Buku III. Pusat Penelitian dan Pengembangan Tanaman Pangan, Bogor. 